\title{
Tanggung Jawab Notaris Dalam Pembuatan Perjanjian Pengikatan Jual Beli Yang Tidak Sesuai Dengan Harga Sebenarnya
}

\author{
Rizki Inmas Pradinisiwi \\ Magister Kenotariatan Fakultas Hukum Universitas Islam Indonesia Yogyakarta Indonesia \\ Jln. Cik Di Tiro No. 1 Yogyakarta Indonesia \\ rizki.inmas@gmail.com
} Key Word:
Notary; notary's code
of ethics; sale and
purchase agreement

\begin{abstract}
There are two problem formulations in this study, namely, first, what is the responsibility of the Notary in the making of a sale and purchase obligation agreement that does not match the actual price? Second, what are the legal consequences of making a binding sale and purchase agreement that does not match the actual price? This research is an empirical research that emphasizes on the problems studied based on the facts that exist and develop in society or research that comes from primary data. The results of the study conclude that first, that the Notary is not responsible for the material truth of the Sale and Purchase Binding Agreement (PPJB) which does not match the actual price because the Notary only pours or confirms the will of the parties into the PPJB deed. So the responsibility lies with the parties. Second, the legal consequences for PPJB are not in accordance with the actual price, namely the PPJB deed made by the Notary still runs according to the agreement of the parties because no parties feel aggrieved and no one has sued to the Court, so the deed is not automatically null and void by law but if there are parties who feel aggrieved can be used as material for a lawsuit to the Court, because the agreement does not meet the objective requirements, namely a certain matter and a lawful cause.
\end{abstract}

\begin{abstract}
Abstrak
Terdapat dua rumusan masalah dalam penelitian ini, yakni, pertama, bagaimana tanggung jawab Notaris dalam pembuatan perjanjian pengikatan jual beli yang tidak sesuai harga sebenarnya? Kedua, bagaimana akibat hukum terhadap pembuatan perjanjian pengikatan jual beli yang tidak sesuai harga sebenarnya? Penelitian ini adalah penelitian empiris yaitu menekankan pada permasalahan yang diteliti berdasarkan kenyataan-kenyataan yang ada dan berkembang dalam masyarakat atau penelitian yang bersumber dari data primer. Hasil penelitian menyimpulkan, pertama, Notaris tidak bertanggung jawab atas kebenaran materiil terhadap Perjanjian Pengikatan Jual Beli (PPJB) yang tidak sesuai harga sebenarnya karena Notaris hanya menuangkan atau mengkonstantir kehendak para pihak kedalam akta PPJB. Sehingga tanggung jawabnya terletak pada para pihak. Kedua, akibat hukum terhadap PPJB tidak sesuai dengan harga sebenarnya yaitu akta PPJB yang dibuat Notaris tersebut tetap berjalan sesuai kesepakatan para pihak karena tidak ada para pihak yang merasa dirugikan dan tidak ada yang menggugat ke Pengadilan, sehingga akta tersebut tidak otomatis batal demi hukum tetapi jika ada pihak yang merasa dirugikan bisa digunakan sebagai materi untuk gugatan ke Pengadilan, karena perjanjian tersebut sudah tidak memenuhi syarat objektif, yaitu suatu hal tertentu dan kausa yang halal.
\end{abstract}

\section{Pendahuluan}

Notaris menurut Pasal 1 ayat (1) Undang-Undang Nomor 2 Tahun 2014 tentang Perubahan atas Undang-Undang Nomor 30 Tahun 2004 tentang Jabatan Notaris (selanjutnya disebut UUJN) adalah "Pejabat Umum yang berwenang untuk membuat 
akta autentik dan memiliki kewenangan lainnya sebagaimana dimaksud dalam undangundang ini atau berdasarkan undang-undang lainnya". Notaris dan Pejabat Pembuat Akta Tanah (PPAT) memiliki kewenangan masing-masing. Pasal 15 huruf (f) UUJN menjelaskan bahwa Notaris memiliki kewenangan dalam membuat akta pertanahan. Secara praktik, Notaris berwenang dalam membuat akta pengikatan jual beli tanah.

PPAT berwenang membuat akta yang sebagaimana diatur di Peraturan Pemerintah Nomor 37 Tahun 1998 tentang Peraturan Jabatan Pejabat Akta Tanah sebagaimana telah diubah dengan Peraturan Pemerintah Nomor 24 Tahun 2016, yaitu melaksanakan kegiatan pendaftaran tanah dengan membuat akta sebagai bukti telah dilakukannya perbuatan hukum tertentu mengenai hak atas tanah atau hak milik atas satuan rumah susun yang akan dijadikan dasar bagi pendaftaran perubahan data pendaftaran tanah yang diakibatkan oleh perbuatan hukum itu meliputi akta jual beli, tukar menukar, hibah, pemasukan ke dalam perusahaan (inbreng), pembagian hak bersama, pemberian hak guna bangunan/ hak pakai atas tanah hak milik, pemberian hak tanggungan dan pemberian kuasa membebankan hak tanggungan. namun tidak selamanya implementasi dari peraturan tersebut berjalan secara baik. Apalagi perjanjian yang dibuat oleh Notaris tersebut adalah jenis dari pengikatan jual beli tanah yang notabene rentan terhadap persengketaan jika notaris tidak mencermati secara hati-hati latar belakang dibuatnya akta pengikatan jual beli tanah tersebut.

Perjanjian pengikatan jual beli (PPJB) merupakan ikatan awal antara penjual dan pembeli yang bersifat di bawah tangan (akta non autentik) sehingga tidak mengikat tanah. Tanah sebagai objek jual beli dengan kata lain tidak menyebabkan beralihnya hak kepemilikan atas tanah dari pihak penjual kepada pihak pembeli. Namun dalam praktik, eksistensi dari pengikatan jual beli tanah ini tidak selalu berjalan lancar atau bahkan rentan terhadap permasalahan hukum.

Permasalahan yang terjadi dalam praktiknya belum tentu seluruh para pihak dapat melanjutkan akta pengikatan jual beli ke akta jual beli sehingga pihak penjual dan pembeli tidak memberikan keterangan secara benar (beriktikad buruk) dalam penentuan nilai nominal perjanjian pengikatan jual beli yang tidak sesuai dengan harga sebenarnya. Permasalahan yang lain adalah Notaris dengan sengaja menyetujui memasukan Nilai Nominal Perjanjian Pengikatan Jual Beli yang tidak sesuai dengan harga sebenarnya, khususnya di Kabupaten Sleman agar Pajak Penghasilan (PPh) diatur dalam Pasal 1 ayat (1) dan (2) Peraturan Pemerintah Nomor 34 Tahun 2016 Tentang Pajak Penghasilan Atas Penghasilan dari Pengalihan Hak Atas Tanah dan/atau Bangunan, dan Perjanjian Pengikatan Jual Beli Atas Tanah dan/atau Bangunan Beserta Perubahannya, yang dikenakan pada penjual dan Pajak BPHTB (Bea Perolehan Hak atas Tanah dan Bangunan) diatur dalam Peraturan Daerah Kabupaten Sleman Nomor 14 Tahun 2010 tentang Bea Perolehan Hak atas Tanah dan Bangunan, tidak terlalu tinggi apabila melanjutkan akta pengikatan jual beli ke akta jual beli. ${ }^{1}$

Tidak menutup kemungkinan nilai transaksi yang ditentukan oleh petugas pajak justru tidak sesuai dengan kenyataan yang sebenarnya karena tidak adanya kepastian mengenai nilai transaksi. Pihak Badan Keuangan dan Aset Daerah (BKAD) telah memiliki

\footnotetext{
${ }^{1}$ Supriadi, Etika dan Tanggung Jawab Profesi Hukum di Indonesia, Sinar Grafika, Jakarta, 2006, hlm. 12.
} 
standarisasi dari setiap daerah mengenai harga-harga objek tanah, ${ }^{2}$ tetapi dengan ditambah bukti pengikatan jual beli bisa dibuat bahan petimbangan atau bukti autentik dan bisa dipertanggung jawabkan tentang isi dari pengikatan jual beli tersebut. Pada implementasinya pengikatan jual beli ini ada yang menuai permasalahan, namun ada juga yang justru sangat terbantu karena setelah pengikatan selesai, bisa dilanjut dengan melakukan pendaftaran hak atas tanah dengan membuat akta jual beli di hadapan PPAT. ${ }^{3}$

Menurut penulis jika pengikatan jual beli tanah tersebut dapat terlaksana dengan baik tanpa menimbulkan permasalahan, artinya Notaris dengan wewenangnya sebagai pejabat umum, dengan turut membantu kelancaran pendaftaran tanah di Indonesia. Namun yang jadi permasalahan, bagaimana jika setelah pengikatan jual beli dibuat, timbul kendala sehingga keberlanjutan pengikatan jual beli ini menjadi terhambat untuk bisa dialihkan penguasaan hak atas tanah nya dengan membuat Akta Jual Beli (AJB) karena pada kenyataannya masih banyak orang yang mengelabui nilai Perjanjian Perikatan Jual Beli (PPJ) tidak sesuai dengan nominal sebenarnya khususnya di Kabupaten Sleman. Para pihak memasukan nilai PPJB tidak sesuai dengan harga sebenarnya dan Notaris tidak bisa menolak akan hal tersebut dan dapat dikatakan bahwa notaris melanggar UUJN dan Kode Etik Notaris. Oleh karenanta, terdapat permasalahan hukum yang menarik untuk diteliti dalam penelitia ini mengenai "Tanggung Jawab Notaris dalam Pembuatan Perjanjian Pengikatan Jual Beli yang tidak sesuai harga sebenarnya"

\section{Rumusan Masalah}

Berdasarkan uraian latar belakang di atas, rumusan masalah dalam penelitian ini yakni, pertama, bagaimana tanggung jawab Notaris dalam pembuatan perjanjian pengikatan jual beli yang tidak sesuai dengan harga sebenarnya? Kedua, bagaimana akibat hukum terhadap perjanjian pengikatan jual beli yang tidak sesuai dengan harga sebenarnya?

\section{Tujuan Penelitian}

Berdasarkan uraian latar belakang dan rumusan masalah di atas, penelitian ini bertujuan untuk mendapatkan hasil yakni, pertama, untuk mengetahui dan mengkaji tanggung jawab Notaris dalam pembuatan perjanjian pengikatan jual beli yang tidak sesuai dengan harga sebenarnya. Kedua, untuk mengetahui dan mengkaji akibat hukum terhadap pembuatan perjanjian pengikatan jual beli yang tidak sesuai dengan harga sebenarnya.

\section{Metode Penelitian}

Penelitian ini termasuk ke dalam pendekatan hukum yang bersifat empiris yang menekankan pada permasalahan yang diteliti berdasarkan kenyataan-kenyataan yang

2 Ady Supratno, "Pengarub Perubahan Zona Nilai Tanah Dan Nilai Jual Objek Pajak Bangunan Terhadap Penerimaan Pajak Bumi Dan Bangunan Perdesaan Dan Perkotaan Kabupaten Sambas”, Artikel Ilmiah, oleh di Program Studi Magister Ilmu Ekonomi Fakultas Ekonomi Dan Bisnis Universitas Tanjungpura.

3 Made Ara Denara Asia Anasangsa, "Perjanjian Pengikatan Jual Beli (PPJB) dalam Transaksi Peralihan Hak. atas Tanah dan/atau Bangunan” Artikel Ilmiah, Fakultas Hukum Universitas Udayana, Bali, 2020. 
ada dan berkembang dalam masyarakat. ${ }^{4}$ Pendekatan penelitian ini yakni pendekatan perundang-undangan. Bahan hukum dalam penelitian ini terdiri dari, pertama, bahan hukum primer berupa peraturan perundang-undangan berkaitan dengan topik penelitian. Kedua, bahan hukum sekunder berupa buku dan literatur berkaitan dengan topik penelitian. Ketiga, bahan hukum tersier. Metode pengumpulan data menggunakan studi dokumen dan studi pustaka. Analisis data yang digunakan adalah analisis data deskriptif kualitatif.

\section{Hasil Penelitian dan Pembahasan}

\section{Tanggung Jawab Notaris dalam Pembuatan Perjanjian Pengikatan Jual Beli yang Tidak Sesuai dengan Harga Sebenarnya}

Notaris memiliki tanggung jawab dalam pelaksanaan kewenangannya. Salah satu kewenangannya adalah membuat PPJB. Notaris dalam pembuatan PPJB ini harus berdasarkan ketentuan peraturan perundang-undangan yang berlaku dan Kode Etik Notaris. Berdasarkan konsekuensi hukum yang berkaitan dengan peralihan hak, dengan ditandatanganinya akta PPJB yang didalamnya terdapat pembayaran atas keseluruhan harga jual beli lunas maupun sebagian (bertahap). Maka PPJB tersebut, dilihat dari hukum perdata merupakan perjanjian pendahuluan sebelum dibuatkannya AJB dihadapan PPAT. Isi dari perjanjian tesebut berupa janji bahwa penjual berjanji menjual hak milik atas tanahnya kepada pembeli, sedangkan pembeli berjanji membeli hak milik atas tanah dari penjual.

Terhadap objek perjanjian pengikatan jual beli yang berupa tanah maka harus mengacu pada hukum pertanahan Indonesia. Dengan adanya pembayaran baik secara lunas maupun bertahap, maka hak milik atas tanah menjadi objek jual beli telah beralih kepada pembeli karena jual beli tersebut telah memenuhi unsur tunai, terang dan riil. Unsur tunai terpenuhi dengan dibayarkan sejumlah uang oleh pembeli kepada penjual, meskipun pembayaran baru sebagian. Unsur terang juga sudah terpenuhi hal ini dapat dilihat dari dibuatnya perjanjian pengikatan jual beli di hadapan pihak ketiga. Pihak ketiga disini adalah pejabat yang berwenang yaitu Notaris dan saksi-saksi instrumenter, sehingga perbuatan hukum yang dilakukan penjual dan pembeli bukan perbuatan yang dilakukan secara diam-diam atau tersembunyi. Notaris juga memastikan bahwa perbuatan itu tidak melanggar ketentuan hukum yang berlaku. Unsur riil juga telah terpenuhi yaitu dengan adanya perbuatan nyata yang dilakukan para pihak dengan membuat akta perjanjian pengikatan jual beli di hadapan Notaris dan dibayarkan uang dari pembeli kepada penjual.

Notaris dalam membuat akta PJJB perlu kehati-hatian karena rentan terhadap masalah dalam pembuatan nilai PPJB yang tidak sesuai dengan nominal sebenarnya atau memanipulasi harga. Namun dalam hal ini, Notaris melakukan usaha sebaik-baiknya dengan melakukan tindakan preventif seperti menuliskan secara rinci, detail, dan selengkap-lengkapnya berdasarkan keterangan dari para pihak di daftar akta PPJB

${ }_{4}$ Soerjono Soekanto, Pengantar Penelitian Hukum, Cetakan ketiga, Universitas Indonesia Press, Jakarta, 1986, hlm. 52 . 
tersebut. ${ }^{5}$ Jika notaris membuat akta secara cermat, hati-hati, dan seksama maka fungsi dari pembuatan akta PPJB akan terwujud yaitu seharusnya yang tertulis dalam perjanjian menunjukan yang sebenarnya dari keinginan para pihak. Oleh karena itu ketika perjanjian akan dibuat, keinginan yang sebenarnya harus diungkapkan seluruhnya. Fungsi perjanjian ini disebut fungsi perjanjian untuk menjaga kejujuran hati dan pikiran para pihak. Menurut Notaris Sutarna, bahwa beliau tidak mau bertanggung jawab terhadap apa yang tidak sesuai yang disampaikan oleh para pihak karena Notaris hanya menerima informasi dari pihak penjual dan pembeli dan tidak ada manipulasi terhadap harga, Jadi berdasarkan apa yang disepakati kedua belah pihak dan tidak bisa mengaturatur soal harga. ${ }^{6}$

Notaris tetap berpegang pada seharusnya seperti apa. Pasti Notaris akan menyarankan apa yang terjadi itu lah yang dituangkan pada akta. ${ }^{7}$ Pada intinya perjanjian yang dibuat tidak menyimpang dan sesuai hukum yang berlaku. Begitu juga dengan para pihak tidak boleh memasukan nilai PPJB yang tidak sesuai dengan harga sebenarnya karena sesuai dengan facta sun servanda (perikatan di lakukan harus ditaati oleh masing-masing pihak) ${ }^{8}$, terdapat dalam akta, digunakan sebagai Undang-Undang bagi yang membuatnya.

Selain itu Para pihak tidak boleh memasukan nilai PPJB yang tidak sesuai dengan harga karena hal tersebut riskan atau membahayakan para pihak sendiri. Misal harga riil atau sebenarnya adalah Rp. 1.000.000.000,00, namun menyuruh Notaris memasukan harga Rp.500.000.000,00. Hal tersebut tentu saja tidak bisa, itu akan menjadi 'bumerang' bagi para pihak sendiri, yang mana sudah dibayarkan Rp.500.000.000,00 yang berarti sudah lunas. Tetapi, terdapat kemungkinan terjadi masalah ditengah perjalanan bahwa penjual meminta kekurangan pembayaran karena secara sebenarnya belum lunas, masalah yang terjadi pembeli tidak mau membayarkan karena dalam PPJB sudah lunas. Berarti terjadi penyelewangan. Notaris tidak akan membuat seperti itu, harus sesuai dengan yang sebenarnya. ${ }^{9}$

Dalam wawancara beberapa notaris di Kabupaten Sleman tersebut, penulis tidak menemukan Notaris yang dengan sengaja menyetujui nilai PPJB tidak sesuai dengan harga sebenarnya karena seorang Notaris harus sesuai dengan apa yang disampaikan oleh para pihak tetapi dalam PPJB menurut Titin Fathonah sebagai Kepala Sub Bidang Penetapan pada Badan Keuangan dan Aset Daerah (BKAD) Kabupaten Sleman banyak orang mengelabui nilai PPJB tidak sesuai dengan harga sebenarnya. Banyak nilai PPJB yang di dalam dokumen para pihak tidak sesuai dengan harga yang ditetapkan oleh BKAD.

${ }^{5}$ Wawancara dengan Notaris Sinto Ari Wibowo, Notaris di Kabupaten Sleman, pada 05 Oktober 2020 pukul 12.00 WIB.

${ }^{6}$ Wawancara dengan Notaris Sutarna, Notaris di Kabupaten Sleman, pada 08 Oktober 2020 pukul 13.30 WIB.

7 Wawancara dengan Notaris Anita Tri Hastuti Notaris di Kabupaten Sleman, pada 07 Oktober 2020 pukul 10.30 WIB.

${ }^{8}$ Wawancara dengan Notaris Sinto Ari Wibowo Notaris di Kabupaten Sleman, pada 05 Oktober 2020 pukul 12.00 WIB.

${ }_{9}$ Wawancara dengan Notaris Eni Wijiastuti, Notaris di Kabupaten Sleman, pada 19 Oktober 2020 pukul 13.30 WIB. 
BKAD selama ini selalu meninjau kewajaran besarnya nilai yang terdapat dalam PPJB dengan menilai kewajaran terhadap nilai PPJB, mengklarifikasi terhadap nominal yang ada di PPJB lalu mendiskusikan terlebih dahulu untuk menilai kewajaran guna penelitian kantor dan penelitian lapangan berdasarkan Peraturan Daerah Kabupaten Sleman Nomor 14 Tahun 2010 tentang Bea Perolehan Hak atas Tanah dan Bangunan,10 walaupun secara legal ada dokumennya.

Berdasarkan uraian tersebut, anggung jawab terhadap nilai PPJB yang tidak sesuai dengan harga sebenarnya terletak pada para pihak itu sendiri karena para pihak yang menghendaki sehingga para pihak yang akan dipanggil untuk menghadap ke kantor BKAD Kabupaten Sleman untuk klarifikasi. Hal tersebut sama dengan hasil wawancara saya dengan salah satu pihak yang pernah membuat PPJB di daerah Kabupaten Sleman yang tidak mau disebut namanya bahwa beliau pernah satu kali mengubah nominal di dalam akta PPJB tersebut guna pembayaran pajak yang tidak terlalu tinggi. ${ }^{11}$

Sebagai Seorang notaris yang taat kepada peraturan perundang-undangan, ketika mengetahui hal tersebut sudah seharusnya notaris memberikan solusi terbaik kepada para pihak yang datang kepadanya, termasuk dalam pembuatan PPJB. Disisi lain para pihak lah yang mempunyai keinginan memasukan nominal tidak sesuai dengan sebenarnya dan hal tersebut diketahui oleh Notaris. Notaris telah memberikan saran tetapi para pihak tetap mempertahankan harga yang tidak sesuai tersebut maka Notaris tidak bisa menolak karena berdasarkan kesepakatan para pihak. Notaris bertanggung jawab atas seluruh isi akta PPJB yang dibuatnya, oleh karena itu Notaris memiliki kewajiban hukum dan kewajiban moral untuk memberikan solusi hukum terbaik, diantaranya menyajikan hak dan kewajiban para pihak secara proporsional di dalam PPJB.

Di samping itu tidak menutup kemungkinan bahwa notaris menyetujui bahwa PPJB tersebut tidak sesuai dengan harga dan dapat dikatakan bahwa notaris ikut dalam penentuan nilai PPJB yang dibuat oleh para pihak tersebut sehingga notaris melanggar UUJN dan Kode Etik Notaris. Seseorang yang menjabat notaris harus mematuhi UUJN dan berpegang pada Kode Etik Notaris. Hubungan antara Peraturan Jabatan Notaris dan Kode Etik Notaris terletak pada ketentuan Kode Etik Notaris yang diangkat dari ketentuan Peraturan Jabatan Notaris dan pengenaan sanksi terhadap pelanggar kedua-duanya. ${ }^{12}$

Notaris dalam mengemban tugasnya harus bertanggung jawab, meliputi:

1) Notaris dituntut melakukan pembuatan akta dengan baik dan benar artinya bahwa akta yang dibuat menaruh kehendak hukum dan permintaan pihak berkepentingan karena jabatannya.

2) Notaris dituntut menghasilkan akta yang bermutu artinya akta yang dibuat itu sesuai dengan aturan hukum dan kehendak pihak yang berkepentingan dalam arti sebenarnya, bukan mengada-ada. Notaris harus menjelaskan kepada pihak berkepentingan kebenaran isi dan prosedur akta yang dibuatnya tersebut.

10 Wawancara dengan Titin Fathonah sebagai Kapala Sub Bidang Penetapan pada Badan Keuangan dan Aset Daerah (BKAD) Kabupaten Sleman, pada 28 September 2020 pukul 09.30 WIB.

11 Wawancara pada 04 November 2020 pukul 11.30 WIB.

12 Roesnastiti Prayitno, Kode Etik Notaris, Universitas Indonesia, Jakarta, 2020, hlm. 61. 
3) Berdampak positif artinya siapapun akan mengakui akta notaris itu mempunyai kekuatan bukti sempurna.

\section{Akibat Hukum terhadap Pembuatan Perjanjian Pengikatan Jual Beli yang Tidak Sesuai dengan Harga Sebenarnya}

Pembuatan akta PPJB harus memperhatikan kaidah-kaidah yang berlaku berkaitan dengan substansi yang disepakati para pihak serta memperhatikan hak dan kewajiban para pihak mengenai segala akibat hukum yang akan timbul. Pada umumnya, orang yang melakukan atau terlibat dalam perjanjian bersedia dan sanggup terlibat dalam kontrak. Pembuatan akta PPJB perlu melihat kapasitas para pihak apakah sanggup untuk menjalankan kontrak dan melunasi seluruh transaksi jual beli tanah tersebut dengan secara seksama dan hati-hati serta memperhatikan itikad baik dari para pihak. Itikad baik para pihak ini salah satunya diwujudkan dalam kejujuran menyampaikan harga jual yang sebenarnya dari transaksi jual beli tanah yang menjadi objek perjanjian. Hal ini karena dalam proses pembuatan PPJB, terkadang menemui kendala, ketika petugas pajak pada Dinas Pendapatan Daerah tidak menerima nilai transaksi yang dipakai sebagai dasar menghitung pajak karena dianggap tidak sesuai dengan nominal sebenarnya dan tidak menutup kemungkinan para pihak sendiri harus hadir secara langsung untuk menjelaskan mengenai harga transaksi yang sebenarnya.

Pasal 1 ayat (3) Peraturan Pemerintah Nomor 34 Tahun 2016 tentang Pajak Penghasilan atas Penghasilan dari Pengalihan Hak atas Tanah dan/atau Bangunan dan Perjanjian Pengikatan Jual Beli atas Tanah dan/atau Bangunan beserta Perubahannya mengatur bahwa penghasilan dari perjanjian pengikatan jual beli atas tanah dan/ atau bangunan dikenai pajak karena tidak dibuat dibawah tangan. Jadi sebelum melakukan penandatanganan akta PJB, pembayaran SSP (Surat Setoran Pajak) penjual wajib dibayarkan secara lunas terlebih dahulu.

Secara dogmatis, menurut Pasal 1868 KUHPerdata bahwa suatu akta autentik adalah akta yang bentuknya ditentukan oleh Undang-Undang (walke in de werrelike vorm is verleden) dan dibuat oleh atau dihadapan pejabat umum di tempat akta tersebut dibuat. Autentik atau tidaknya suatu akta notaris tidaklah cukup apabila akta tersebut dibuat oleh di hadapan notaris saja. Cara membuat akta autentik harus menurut ketentuan yang ditetapkan oleh Undang-Undang. Akta yang dibuat oleh seorang pejabat tanpa ada wewenang dan tanpa ada kemampuan untuk membuatnya atau tidak memenuhi syarat, tidak dapat dianggap sebagai akta autentik.13 Dalam Pasal 1868 KUHPerdata menyebutkan "Suatu akta autentik ialah suatu akta yang dibuat dalam bentuk yang ditentukan undang-undang oleh atau dihadapan pegawai-pegawai umum yang berkuasa untuk itu, di tempat dimana akta itu dibuat". Setiap akta autentik melekat nilai kekuatan pembuktian yang sempurna (perfec volledig) dan yang mengikat (binding - binden). Jadi kedudukan akta autentik sebagai alat bukti langsung mengandung kekuatan pembuktian yang sempurna dan mengikat. ${ }^{14}$

13 Sudikno Mertokusumo, Hukum Acara Perdata Indonesia, Yogyakarta, Liberty, 2006, hlm. 142-143.

14 Syamsudin Aboebakar, "Pengarahan/Ceramah Umum Mengenai Perkembangan Hukum Perdata Tertulis di Indonesia", Jurnal Media Notariat, Nomor 34-37 Januari-Oktober, 1995, hlm 20-28. 
Mengenai akibat hukum yang diterima bagi Notaris yang ikut menyetujui nilai PPJB tidak sesuai dengan harga sebenarnya, tentunya yang dirugikan adalah Kantor Pajak baik pada Dinas Pendapatan Daerah maupun pada pusat, KPP Pratama. Terbukti bahwa ketika proses validasi pajak BPHTB (Bea Perolehan Hak Atas Tanah) harganya lebih rendah maka oleh petugas Dinas Pendapatan Daerah akan di keluarkan Berita Acara (BA). Pasal 14 ayat (2) Peraturan Bupati Sleman Nomor 32 Tahun 2018 tentang Tata Cara Pemungutan Bea Perolehan Hakk atas Tanah dan Bangunan (selanjutnya disebut Perbup Sleman 32 Tahun 2018) menyatakan apabila berdasarkan Laporan Hasil Penelitian SSPD (Surat Setoran Pajak Daerah), ternyata pajak yang harus disetor lebih besar daripada yang telah diajukan oleh wajib pajak, wajib pajak diminta untuk memperbaiki SSPD atau mengajukan SSPD lagi sesuai dengan Laporan Hasil Penelitian Kantor dan/ atau lapangan.

Pasal 14 ayat (3) Perbup Sleman 32 Tahun 2018 bahwa apabila wajib pajak setuju dengan laporan hasil penelitian dapat mengajukan klarifikasi. Para pihak harus hadir secara langsung dan bisa membuktikan dengan membawa dokumen PPJB tersebut. Ketika para pihak sudah bisa membuktikan bahwa harga tersebut sudah sebenarnya maka petugas baru akan mengkonfirmasi validasi tersebut. ${ }^{15}$ Hal tersebut sesuai dengan Pasal 14 ayat (4) Perbup Sleman 32 Tahun 2018 bahwa klarifikasi atas laporan hasil penelitian sebagaimana dimaksud pada ayat (3) diajukan melalui permohonan klarifikasi kepada Kepala BKAD disertai dengan bukti pendukung yang akurat.

Berbeda dengan Pajak Penghasilan (PPh) yang ditentukan oleh petugas KPP Pratama setempat, walaupun dari Kantor Dinas Pendapatan Daerah sudah tervalidasi tetapi dari Kantor KPP Pratama belum tentu terkonfimasi karena dianggap menyimpang, pihak KPP Pratama sendiri dalam menentukan nilai wajib pajak sesuai dengan harga pasar sedangkan dari pihak Dinas Pendapatan Daerah sesuai dengan harga sebenarnya maka sering kali terjadi ketidaksinkronan dan akan dikeluarkan surat yang dikirimkan kepada para pihak tersebut. Harga pasar adalah NJOP (Nilai Jual Objek Pajak) karena NJOP nilai yang ditentukan oleh kantor pajak, maka dianggap nilai pasar selama belum ada aturan yang lebih spesifik menentukan harga pasar. Jadi, ketika akan dibuatnya PPJB tersebut dimasukan nominal tidak sebenarnya tentu petugas pajak dari masing-masing kantor BKAD ataupun KPP Pratama akan tetap mengkonfirmasikan kepada para pihak ataupun Notaris dengan membawa bukti atau dokumen yang diperlukan dan ketika bukti ada, baru bisa membayar pajak, jika tidak dapat membuktikan maka standar harga yang dikeluarkan oleh BKAD dan Kantor Pajak KPP Pratama tersebut yang dipakai. Namun kantor pajak harusnya memiliki aturan yang spesifik mengenai harga pasar yang wajar sebab adanya kekosongan hukum akan istilah ini.

Mengenai akta yang berisikan harga PPJB yang tidak sesuai dengan sebenarnya, Akta tersebut tetap berjalan sesuai dengan kesepakatan para pihak karena tidak ada para pihak yang merasa dirugikan dan tidak ada yang menggugat ke Pengadilan. ${ }^{16}$ Tidak otomatis batal demi hukum tetapi jika terjadi permasalahan bisa digunakan sebagai materi untuk gugatan ke Pengadilan, karena ada pihak yang merasa dirugikan dan

15 Wawancara dengan Titin Fathonah sebagai Kapala Sub Bidang Penetapan pada Badan Keuangan dan Aset Daerah (BKAD) Kabupaten Sleman, pada 09 November 2020 pukul 11.00 WIB.

16 Wawancara dengan Notaris Eni Wijiastuti, Notaris di Kabupaten Sleman, pada 19 Oktober 2020 pukul 13.30 WIB. 
menggugat akta tersebut dan tidak memenuhi syarat objektif yaitu suatu hal tertentu dan kausa yang halal. ${ }^{17} \mathrm{Hal}$ ini sesuai dengan yang dikatakan oleh R. Subekti, bahwa jika perjanjian sudah tidak memenuhi syarat objektif, yaitu suatu hal tertentu dan kausa yang halal, ternyata masih ada yang mengajukan gugatan atau tuntutan atas hal tersebut, maka hakim diwajibkan karena jabatannya menyatakan bahwa tidak pernah ada suatu perjanjian atau perikatan. ${ }^{18}$

\section{Penutup}

Berdasarkan uraian pembahasan di atas, terdapat 2 kesimpulan, yakni, pertama, dalam hal tanggung jawab Notaris terhadap Perjanjian Pengikatan Jual Beli (PPJB) yang tidak sesuai harga sebenarnya, Notaris tidak bertanggung jawab atas kebenaran materiil terhadap Perjanjian Pengikatan Jual Beli (PPJB) karena Notaris hanya menuangkan atau mengkonstantir kehendak para pihak kedalam akta Perjanjian Pengikatan Jual Beli (PPJB). Notaris hanya membuat isi perjanjian berdasarkan kesepakatan para pihak. Selain itu, notaris sudah melakukan usaha sebaik-baiknya dengan melakukan tindakan preventif seperti menuliskan secara rinci, detail, dan selengkap-lengkapnya berdasarkan keterangan dari para pihak, sehingga tanggung jawabnya terletak pada para pihak. Dalam hal ini para pihak yang akan dipanggil oleh Kantor Pajak untuk dimintai keterangan yang sebenarnya. Notaris hanya sebatas saksi dalam perjanjian tersebut.

Kedua, mengenai akibat hukum terhadap Perjanjian Pengikatan Jual Beli (PPJB) tidak sesuai dengan harga sebenarnya yaitu akta Perjanjian Pengikatan Jual Beli (PPJB) yang dibuat Notaris tersebut tetap berjalan sesuai kesepakatan para pihak karena tidak ada para pihak yang merasa dirugikan dan tidak ada yang menggugat ke Pengadilan, sehingga akta tersebut tidak otomatis batal demi hukum. Tetapi jika ada pihak yang merasa dirugikan bisa digunakan sebagai materi untuk gugatan ke Pengadilan, karena perjanjian tersebut sudah tidak memenuhi syarat objektif, yaitu suatu hal tertentu dan kausa yang halal.

\section{Daftar Pustaka}

\section{Buku}

Mertokusumo, Sudikno, Hukum Acara Perdata Indonesia, Yogyakarta, Liberty, 2006.

Prayitno, Roesnastiti, Kode Etik Notaris, Universitas Indonesia, Jakarta, 2020.

Soekanto, Soerjono, Pengantar Penelitian Hukum, Cetakan ketiga, Universitas Indonesia Press, 1986.

Subekti, R., Hukum Perjanjian, Intermasa, Jakarta, 2005.

Supriadi, Etika dan Tanggung Jawab Profesi Hukum di Indonesia, Sinar Grafika, Jakarta, 2006.

\section{Artikel dan Jurnal}

Ady Supratno, "Pengaruh Perubahan Zona Nilai Tanah Dan Nilai Jual Objek Pajak Bangunan Terhadap Penerimaan Pajak Bumi Dan Bangunan Perdesaan Dan Perkotaan Kabupaten Sambas", Artikel Ilmiah, oleh di Program Studi Magister

17 Wawancara dengan Notaris Sutarna Notaris di Kabupaten Sleman, pada 08 Oktober 2020 pukul 13.30 WIB.

18 R. Subekti, Hukum Perjanjian, Intermasa, Jakarta, 2005, hlm. 22. 
Ilmu Ekonomi Fakultas Ekonomi Dan Bisnis Universitas Tanjungpura, Pontianak, 2018.

Made Ara Denara Asia Anasangsa,"Perjanjian Pengikatan Jual Beli (PPJB) dalam Transaksi Peralihan Hak atas Tanah dan/ atau Bangunan", Artikel Ilmiah, Fakultas Hukum Universitas Udayana, Bali, 2020.

Syamsudin Aboebakar, "Pengarahan/ Ceramah Umum Mengenai Perkembangan Hukum Perdata Tertulis di Indonesia", Jurnal Media Notariat, Nomor 34-37 Januari-Oktober, 1995.

\section{Peraturan Perundang-Undangan}

Undang-Undang Dasar Negara Republik Indonesia Tahun 1945

Kitab Undang-Undang Hukum Perdata (KUHPerdata)

Undang-Undang Rebuplik Indonesia Nomor 5 Tahun 1960 tentang Peraturan Dasar Pokok-Pokok Agraria

Undang-Undang Nomor 2 Tahun 2014 tentang perubahan atas Undang-Undang Nomor 30 Tahun 2004 tentang Jabatan Notaris

Undang-Undang Nomor 28 Tahun 2009 tentang Pajak Daerah dan Retribusi Daerah

Peraturan Pemerintah Nomor 34 Tahun 2016 Tentang Pajak Penghasilan Atas Penghasilan dari Pengalihan Hak Atas Tanah dan/atau Bangunan, dan Perjanjian Pengikatan Jual Beli Atas Tanah dan/atau Bangunan Beserta Perubahannya

Peraturan Daerah Kabupaten Sleman Nomor 14 Tahun 2010 tentang Bea Perolehan Hak atas Tanah dan Bangunan

Peraturan Bupati Sleman Nomor 32 Tahun 2018 tentang Tata Cara Pemungutan Bea Perolehan Hak atas Tanah dan Bangunan 